\title{
STRATEGI PENANGGULANGAN KENAKALAN REMAJA DI KELURAHAN BELAWAKECAMATAN BELAWA KABUPATEN WAJO
}

\author{
Najia Angraini, Ramli, Zulfah \\ Institut Agama Islam Negeri (IAIN) Parepare \\ Email: Najia@gmail.com
}

\begin{abstract}
The many problems faced in life that cause a lot of negative access that is very troubling to the community. Access is, among others, increasingly widespread irregularities in the norms of religious and social life that are manifested in the form of juvenile delinquency. The purpose of this study was to find out what forms of juvenile delinquency occurred in Belawa Village, Belawa District, Wajo District. Knowing what strategies are used to overcome juvenile delinquency in Belawa Village, Belawa District, Wajo Regency. Then find out how the influence of juvenile delinquency strategies carried out by the government of Belawa Village, Belawa District, Wajo Regency.

This research method uses a qualitative descriptive approach and in data collection using the method of observation, interviews, observing and documentation. As for the data analysis technique used is an inductive analysis technique, meaning that the data obtained in the field is specifically described in words that draw conclusions are general.

The results of the study are related to juvenile delinquency coping strategies in Belawa Village, Belawa District, Wajo Regency, namely: (1) Forms of juvenile delinquency that occur in Belawa Village include: racing and recklessness, using glue (fox glue), drinking oplosan ( komix), drinking liquor and drugs (2) The strategy carried out by the police in collaboration with the government of Belawa Village, religious leaders, and the community, including: counseling / socialization, patrolling, raids to sellers, parental attention, planting religious knowledge (3) Efforts to overcome juvenile delinquency committed by the government of Belawa Village, religious leaders, and parents have been maximized. Actions that are preventive ineffective, repressive have been effective and curative have been effective enough to overcome juvenile delinquency.
\end{abstract}

Keywords: Strategy, Countermeasures, Juvenile Delinquency

\section{PENDAHULUAN}

Di Indonesia masalah kenakalan remaja dirasa telah mencapai tingkat yang cukup meresahkan bagi masyarakat. Kondisi ini memberikan dorongan yang kuat kepada pihak-pihak yang bertanggung jawab mengenai masalah kenakalan remaja 
ini. ${ }^{1}$ Hal ini lantas menjadi pembahasan penulis karena masa depan remaja akan menjadi tonggak kemajuan bangsa ke arah yang lebih baik, kenakalan remaja lantas menjadi persoalan sosial yang harus dicegah karena akan menyebabkan penyimpangan perilaku. Adapun gambaran kenakalan remaja dapat kita lihat di media cetak maupun elektronik atau bahkan dapat diketahui langsung oleh kita sendiri, tawuran antar pelajar, perkelahian antar pelajar, sering ditemukannya senjata tajam, buku-buku atau gambar porno, obat-obat terlarang, minuman keras yang dibawa remaja baik di sekolah maupun di luar sekolah.

Berdasarkan observasi awal, data remaja di Kelurahan Belawa pada tahun 2017 usia 16 tahun sampai 18 tahun berjumlah 216 orang. Jumlah remaja laki-laki 108 orang dan perempuan 108 orang. ${ }^{2}$ Salah satu kasus kenakalan remaja diantaranya menggunakan lem atau sering dikenal dengan istilah "Mallem (Lem Fox)” yang sangat marak dan semakin memprihatinkan. Perbuatan mallem ini merupakan faktor awal seseorang menggunakan narkoba. Narkoba juga merupakan salah satu kenakalan yang bisa digolongkan dalam kenakalan berat.Kasus kenakalan remaja yang dampaknya bisa meresahkan masyarakat sangat perlu untuk ditanggulangi melihat remaja yang merupakan generasi penerus bangsa.Oleh karena itu, orang tua harus mengawasi dan memperhatikan anak di dalam aktifitas kesehariannya, baik di lingkungan rumah maupun di lingkungan luar rumah.

Selain itu, kasus lainnya yang terjadi pada remaja dan dampaknya bisa meresahkan masyarakat, seperti balapan liar dan ugal-ugalan yang membuat masyarakat terganggu akan hal itu, mengonsumsi obat-obat terlarang, minum minuman oplosan (komix) ataupun minum minuman keras yang dilakukan remaja baik itu di lingkungan sekolah maupun di lingkungan luar sekolah. Perkelahian antar pelajarpun juga biasa terjadi dan tak jarang diantara mereka bisa saja berurusan dengan pihak kepolisian.

\footnotetext{
${ }^{1}$ Sudarsono, Kenakalan Remaja (Jakarta: Rineka Cipta,2012), h.2.

${ }^{2}$ Kelurahan Belawa, Data Penduduk Kelurahan Belawa. (Diambil pada tanggal 5 September 2017)
} 
Najia Angraini, Strategi Penanggulangan Kenakalan...

Kasus-kasus kenakalan remaja yang terjadi bukan hanya di Kelurahan Belawa tetapi daerah lain pun juga dapat terjadi hal tersebut terkait tentang remaja dan ini sangat perlu untuk diperhatikan, melihat kemajuan teknologi informasi dan komunikasi saat ini sangat besar pengaruhnya terhadap pertumbuhan dan perkembangan remaja, baik itu pertumbuhan fisik maupun psikisnya. Berdasarkan permasalahan dan fenomena remaja tersebut, maka penulis merasa tertarik untuk mengkaji hal tentang "Strategi Penanggulangan Kenakalan Remaja di Kelurahan Belawa Kecamatan Belawa Kabupaten Wajo".

\section{PEMBAHASAN}

Bentuk-Bentuk Kenakalan Remaja di Kelurahan Belawa Kecamatan Belawa Kabupaten Wajo

Bentuk-Bentuk Kenakalan Remaja di Kelurahan Belawa

Ada berbagai macam bentuk atau jenis-jenis kenakalan remaja yang dilakukan oleh para remaja, apalagi memasuki era yang serba modern ini, dengan adanya berbagai budaya luar yang masuk akibat pengaruh teknologi sehingga mempengaruhi pola hidup remaja di Indonesia.Dari hasil penelitian, ada beberapa bentuk kenakalan remaja yang terjadi di Kelurahan Belawa Kecamatan Belawa Kabupaten Wajo.

1. Balapan Liar dan Ugal-ugalan

Saat ini banyak anak remaja yang terjerumus pada kenakalan salah satunya adalah balapan liar.Balapan liar ini bukan hanya dilakukan oleh remaja, namun bahkan anak SD pun sudah bisa melakukan balapan liar.Sering kita jumpai anakanak yang masih umuran SD sudah bisa mengendarai sepeda motor, dan tak jarang mereka mengendarai sepeda motornya dengan kecepatan tinggi.

Dari hasil penelitian tentang balapan liar ini, salah satu yang penulis wawancarai mengungkapkan bahwa balapan liar merupakan salah satu kenakalan 
remaja yang terjadi di Kelurahan Belawa, yaitu remaja yang pernah melakukan balapan: "kenakalan yang pernah saya lakukan balapan"3

Dari hasil wawancara tersebut ternyata memang balapan liar ini terjadi di Kelurahan Belawa karena remaja itu sendiri yang menyatakan bahwa ia pernah melakukan balapan liar dan memang balapan liar ini merupakan salah satu bentuk kenakalan remaja yang terjadi. Hal ini juga dipertegas oleh Kapolsek Kecamatan Belawa Bapak Bangsawan sebagai berikut: "bentuk-bentuk kenakalan remaja itu balapan pernah terjadi”,

Berdasarkan hasil wawancara dengan Bapak Bangsawan penulis dapat katakan bahwa balapan liar ini terjadi bukan hanya di kota-kota besar saja tetapi di Kelurahan Belawa juga terjadi balapan liar.Keluhan masyarakat tentang balapan liar ini sudah sering dan sangat meresahkan masyarakat.

Selain balapan liar, salah satu fenomena kenakalan remaja yang sering kita lihat di jalan raya dan yang terjadi di Kelurahan Belawa adalah ugalugalan.Remaja sering kali memainkan gas motornya dengan kecepatan yang tinggi.Ugal-ugalan ini sangat meresahkan masyarakat karena knalpot atau bunyi dari suara motornya sangat menganggu pendengaran kita. Dia juga mendahului pengendara yang lain dan ingin tampil paling depan di antara para pengguna jalan yang lainnya.

Tidak hanya itu, remaja yang ugal-ugalan di jalanan sangat tidak peduli dengan keselamatannya sendiri maupun keselamatan orang lain. Hasil wawancara dari tokoh agama yaitu M. Najib T, mengatakan:

"Bentuk kenakalan remaja yang terjadi di Kelurahan Belawa antara lain ugal-ugalan",

Dari hasil wawancara tersebut, ugal-ugalan ini juga termasuk salah satu bentuk kenakalan remaja yang terjadi di Kelurahan Belawa.Dan tak jarang

\footnotetext{
${ }^{3}$ Muammar, Remaja, Kel. Belawa, Kec. Belawa, Wawancara oleh penulis di Belawa, Tanggal 07 November 2017

${ }^{4}$ Bangsawan, KAPOLSEK Kec. Belawa, Wawancara oleh penulis di Belawa, Tanggal 09 November 2017

${ }^{5}$ M. Najib T, Tokoh Agama, Kec. Belawa, Wawancara oleh penulis di Belawa, Tanggal 08 November 2017
} 
kenakalan ugal-ugalan ini sangat meresahkan dan membuat masyarakat terganggu. Kapolsek Kecamatan Belawa juga mengatakan hal demikian:

"Bentuk-bentuk kenakalan remaja yang juga pernah terjadi di Kelurahan Belawa yaitu ugal-ugalan"6

Dari hasil wawancara dengan Kapolsek Kecamatan Belawa menurut penulis bahwa ugal-ugalan ini sering terjadi di Kelurahan Belawa dan di Kecamatan Belawa pada umumnya. Jadi memang kenakalan remaja ugal-ugalan ini yang terjadi di Kelurahan Belawa sangat perlu untuk diperhatikan, apalagi sangat mengganggu masyarakat ditambah jika suara knalpot dari motor remaja tersebut sangat keras.

\section{Menggunakan Lem (Lem Fox)}

Kenakalan lain yang terjadi di Kelurahan Belawa adalah menggunakan lem namun di Kelurahan Belawa remaja dan masyarakat menyebutnya dengan istilah "Mallem", di kota-kota besar lebih dikenal dengan sebutan "ngelem". Bagi orang awam memakai lem itu untuk melekatkan sesuatu seperti fungsi lem pada umumnya.Tetapi itu salah, karena mallem ini merupakan bentuk kenakalan menggunakan lem misalnya lem fox atau lem castol kemudian dihisap untuk mendapatkan sensasi mabuk. Dengan menghisap lem fox atau lem castol tersebut dapat membuat seseorang melayang dan berhalusinasi tinggi. Mallem ini konon katanya dapat memberikan efek kegembiraan.

3. Minum Minuman Oplosan (Komix)

Kenakalan selanjutnya adalah minuman oplosan atau yang lebih dikenal dengan sebutan "komix".Penyalahgunaan obat komix sudah menjadi rahasia umum. Komix yang kita kenal adalah obat yang diminum untuk melegakan tenggorokan dan batuk, justru malah disalahgunakan oleh remaja. Minuman oplosan ini ternyata dijadikan remaja sebagai obat penenang dan minuman yang memabukkan.

${ }^{6}$ Bangsawan, KAPOLSEK Kec. Belawa, Wawancara oleh penulis di Belawa, Tanggal 09 November 2017 


\section{Minum Minuman Keras}

Minuman keras atau yang biasa dikenal dengan nama MIRAS adalah minuman memabukkan dan dapat membahayakan remaja dan harus dijauhi karena itu bisa merusak masa depan remaja. Minuman keras ini mungkin sudah tidak asing lagi dan seringkita jumpai, baik itu dimasyarakat, di cafe maupun ditempatumum yang lainnya. Minuman keras ini merupakan salah satu kenakalan yang meresahkan masyarakat. Kenapa?Karena ketika seseorang telah mengkonsumsi yang namanya minuman keras, efeknya bisa saja membuat si pengguna bisa kehilangan kesadaran.

\section{Narkoba}

Narkoba merupakan zat adiktif yang apabila dimasukkan didalam tubuh manusia baik itu dimasukkan di dalam mulut, dihirup maupun disuntikkan dapat merubah pikiran, perasaan dan perilaku seseorang.Narkoba merupakan salah satu kenakalan remaja yang rananya sudah sampai pada rana kriminal. Narkoba yang apabila dikonsumsi satu kali dapat membuat seseorang kecanduan dan ketergantungan akan barang tersebut.

\section{Faktor Penyebab Terjadinya Kenakalan Remaja}

Hampir setiap hari baik media massa cetak maupun elektronik memberitakan tentang perilaku kenakalan remaja. Sebagai orang tua ataupun masyarakat pasti sangat prihatin melihat dan memperhatikan hal tersebut. Tentu harapan semua orang menginginkan agar kelak di kemudian hari setelah dewasa anak-anaknya bia menjadi manusia yang berguna, kuat dan tangguh menghadapi segala tantangan zaman, patuh terhadap orangtua, berprestasi di sekolahnya, sopan santun dan selalu rendah hati berbuat kepada sesama.

Namun untuk mewujudkan hal tersebut tentu tidak akan mudah. Remaja yang merupakan generasi penerus bangsa harus mampu menghadapi segala tantangan dan rintangan agar remaja tidak hanyut dan terjerumus pada perilaku yang negatif. Tentu ketika remaja yang dulunya baik, sabar dan patuh tiba-tiba berubah menjadi kasar, suka membantah dan susah diatur maka sangat 
memprihatinkan. Dari hasil penelitian, penulis menemukan ada beberapa faktor yang menyebabkan remaja melakukan kenakalan.

\section{Faktor Keluarga (Orangtua)}

Pada dasarnya keluarga merupakan tempat seorang anak bisa tumbuh dan berkembang dengan sempurna, baik itu jasmani maupun rohani.Anak bisa mendapatkan perhatian, kasih sayang, serta dukungan dari orangtua.Namun sebaliknya, jika di dalam keluarga seorang anak tidak bisa mendapatkan hal tersebut maka yang terjadi adalah remaja melampiaskannya diluar rumah. Seperti yang diungkapkan dari hasil wawancara sebagai berikut:

"Remaja yang melakukan kenakalan faktornya dari orangtua biasa, artinya orangtuanya kawin lagi, sehingga remaja terbengkalai kehidupannya, orangtuanya tidak dihiraukan lagi, sehingga pelampiasannya lari kesitu"'

Berdasarkan hasil wawancara Lurah Kelurahan Belawa, Abd.Kadir,

S.Sos bahwa faktor yang membuat remaja melakukan kenakalan biasanya dari orangtua. Orangtua yang bercerai kemudian menikah lagi hingga membuat kehidupan anaknya atau remaja ini terbengkalai hingga mencari hal lain yang bisa membuat dirinya tenang. Orangtuanya sudah tidak dihiraukan lagi, karena dia sudah merasa bebas hingga akhirnya pelampiasan rasa kecewanya dari orangtua membuatnya terjerumus ke kenakalan remaja.

2. Rasa Ingin Tahu yang Tinggi

Selain faktor keluarga dan faktor lingkungan, faktor yang lain yang membuat remaja melakukan kenakalan adalah rasa ingin tahu yang tinggi. Di masa remaja, mereka memiliki rasa ingin tahu yang sangat tinggi.Seringkali anak remaja bahkan anak kecil sekalipun ingin terus mencoba hal yang baru. Namun, mereka tidak pernah mengetahui apa dampak baik dan buruknya hal yang ingin mereka coba itu. Hal ini diungkapkan oleh Bapak Kapolsek Kecamatan Belawa, Bangsawan tentang faktor kenakalan remaja yaitu sebagai berikut:

${ }^{7}$ Abd. Kadir, Lurah Kel. Belawa, Kec. Belawa, Wawancara oleh penulis di Belawa, Tanggal 07 November 2017 
"Yang menyebabkan remaja melakukan kenakalan, itukan kalo remaja itu kan istilahnya mempunyai jiwa yang selalu ingin tahu akan hal yang baru, selalu ingin mencoba sesuatu, mau dikatakan hebat, itu faktor yang menimbulkan terjadi kenakalan remaja sementara mereka belum tahu dampak-dampak negatif yang ditimbulkan untuk melakukan suatu kenakalan"8

Dari hasil wawancara dengan Kapolsek Kecamatan Belawa bahwa remaja yang melakukan kenakalan faktornya karena remaja selalu mempunyai jiwa dan rasa ingin tahu yang tinggi, dalam artian ketika remaja melihat sesuatu yang belum pernah mereka lakukan dan remaja itu tertarik maka dari situlah remaja ingin mencoba hal yang baru itu sehingga meraka tidak tahu akan dampak yang akan ditimbulkan dari rasa ingin tahunya itu. Remaja selalu ingin dikatakan hebat, entah itu ditemannya maupun di lingkungan tempat mereka tinggal.

\section{Stres}

Stres merupakan salah satu faktor dalam diri remaja yang mendorong remaja untuk melakukan kenakalan. Stres yang berlebihan yang dirasakan oleh remaja akan membuatnya lebih mudah melakukan tindakan-tindakan nakal dan nekat yang dapat merugikan orang lain di sekitarnya. Stres yang berkepanjangan juga tidak baik untuk seseorang karena jangan sampai membuat seseorang menjadi gila karena terlalu banyaknya pikiran serta masalah yang dihadapi.

4. Pengaruh Televisi

Selain faktor di atas, faktor kenakalan remaja yang lainnya adalah pengaruh televisi.Tidak dapat kita pungkiri bahwa teknologi informasi dan komunikasi sudah semakin berkembang, cepat dan mudah. Dunia teknologi yang semakin canggih, kita lebih mudah mengetahui informasi di berbagai media, disisi lain juga membawa dampak negatif yang cukup meluas di berbagai lapisan masyarakat.

5. Ingin dikatakan Hebat

\footnotetext{
${ }^{8}$ Bangsawan, KAPOLSEK Kec. Belawa, Wawancara oleh penulis di Belawa, Tanggal 09 November 2017
} 
Faktor selanjutnya yang membuat remaja melakukan kenakalan adalah karena ingin dikatakan hebat. Siapa sangka remaja yang selalu berbuat nakal kemudian memperlihatkannya di depan umum dan ditengah banyak orang ternyata ingin dikatakan hebat dalam artian ingin diperhatikan. Hal tersebut bukannya membuat orang kagum dan terkesima tetapi malah membuat orang terganggu akan hal itu.

\section{Dampak Kenakalan Remaja}

1. Dampak Terhadap Diri Sendiri

Dampak dari kenakalan remaja sudah pasti akan berdampak negatif, namanya saja kenakalan pasti kebanyakan hal yang buruk yang terjadi. Dampak dari kenakalan remaja sudah pasti berimbas pada dirinya sendiri.

2. Dampak Terhadap Keluarga (Orangtua)

Remaja yang labil pada umumnya akan mudah terpengaruh akan hal yang baru dan itu sangat rawan remaja melakukan hal-hal negatif. Dampak kenakalan remaja selain merusak dirinya sendiri juga berdampak pada keluarga terutama orangtua remaja, seperti yang dikatakan oleh tokoh agama Kelurahan Belawa:

"Sudah jelas kalo menurut saya tidak ada keluarga yang senang terhadap itu.Tapi keluarga mungkin $80 \%$ tidak mampu lagi itu membina anaknya karena anak baru ditegur sudah mau melawan. Jadi intinya kalo saya itu remaja tidak lagi menjaga nama baik orangtua dan keluarganya dan pemerintah. Kan sudah ditegur pemerintah baik melalui pengumuman dan atau apa napigau matoi melo napegau."

Berdasarkan hasil wawancara dengan tokoh agama Kelurahan Belawa menurut penulis bahwa dampak dari kenakalan remaja ini di keluarga atau orangtua adalah remaja sudah tidak bisa menghormati dan mendengar perkataan dari orangtuanya sendiri, selalu ingin melawan ketika ditegur dan orangtua sudah tidak mampu lagi untuk membinanya, ini juga berdampak pada pemerintah karena tidak mematuh aturan dari pemerintah. Dia hanya seenaknya saja, melakukan apasaja yang ingin dilakukannya.

3. Dampak Terhadap Masyarakat

\footnotetext{
${ }^{9}$ M. Najib T, Tokoh Agama, Kec. Belawa, Wawancara oleh penulis di Belawa, Tanggal 08 November 2017
} 
Dampak kenakalan remaja yang lain selain berdampak pada diri sendiri dan dampak pada orangtua atau keluarga adalah dampak kepada masyarakat. Remaja yang sudah terjerumus di kenakalan remaja suatu hari akan dikucilkan akibat perbuatannya sendiri, karena ulahnya itu dapat membuat masyarakat terganggu, seperti yang dikatakan Lurah Kelurahan Belawa sebagai berikut:

"Dampaknya di masyarakat, di lapangan dia selalu teriak, lapangan kan dekat dari rumah sakit kemudian saya larang dan menyuruhnya pulang, jadi dampaknya sama masyarakat artinya ketentraman masyarakat terganggu" 10

\section{Strategi Penanggulangan Kenakalan Remaja di Kelurahan Belawa Kecamatan Belawa Kabupaten Wajo}

Keresahan yang ditimbulkan remaja sebenarnya menjadi tanggung jawab semua pihak, mulai dari orangtua remaja, guru di sekolah, masyarakat, serta pemerintah setempat.Jika dilihat dari faktor penyebab kenakalan remaja, orangtua hingga pemerintah semuanya terlibat dan memberi dampak pada semuanya. Strategi penanggulangan kenakalan remaja sudah seharusnya diatasi oleh pemerintah.Pemerintah Desa/Kelurahan mempunyai peranan yang penting dalam penanggulangan tersebut.

Selain pemerintah setempat yang mempunyai peranan dalam menanggulangi kenakalan remaja tetapi masyarakatpun juga seharusnya membantu pemerintah dalam menanggulangi kasus kenakalan remaja ini.Di samping masyarakat orangtuapun juga turut andil dan lebih besar peranannya karena orangtua merupakan guru pertama dalam tumbuh kembang remaja tersebut.Berikut tabel strategi penanggulangan kenakalan remaja serta sifatnya yang dilakukan pemerintah Kelurahan Belawa.

\footnotetext{
${ }^{10}$ Abd. Kadir, Lurah Kel. Belawa, Kec. Belawa, Wawancara oleh penulis di Belawa, Tanggal 07 November 2017
} 
Najia Angraini, Strategi Penanggulangan Kenakalan...

Tabel: Strategi Penanggulangan dan Sifanya

\begin{tabular}{|l|l|l|}
\hline No & \multicolumn{1}{|c|}{ Sifat } & \multicolumn{1}{|c|}{ Strategi Penanggulangan } \\
\hline 1 & Preventif & 1. Penyuluhan/Sosialisasi \\
& & 2. Patroli \\
& & 3. Perhatian Orangtua \\
& & 4. Penanaman Ilmu Agama \\
\hline 2 & Represif & 1. Razia ke Penjual-penjual \\
& & 2. Perhatian Orangtua \\
\hline 3 & Kuratif & 2. Perhatian Orangtua \\
& &
\end{tabular}

\section{Penyuluhan/Sosialisasi}

Penyuluhan atau sosialisasi merupakan salah satu strategi yang bisa dilakukan baik itu dari pihak kepolisian maupun pemerintah.Penyuluhan atau sosialisasi ini dilakukan oleh pemerintah Kelurahan Belawa dalam menanggulangi kenakalan remaja. Hal ini dikatakan oleh Kapolsek Kecamatan Belawa sebagai berikut:

"Kita keliling di sekolah-sekolah untuk memberikan penyuluhan tentang kenakalan remaja, dampak yang ditimbulkan daripada kenakalan remaja"11

Berdasarkan hasil wawawancara dengan Bapak Kapolsek Kecamatan

Belawa bahwasanya pihaknya dari kepolisian keliling dari sekolah ke sekolah yang lain untuk memberikan penyuluhan tentang kenakalan remaja. Bukan hanya itu, pihak kepolisian juga memberikan tentang dampak dan bahaya yang ditimbulkan dari remaja yang terjerumus dalam kenakalan remaja.

Penyuluhan atau sosialisasi yang dilakukan pemerintah Kelurahan Belawa bersifat preventif karena strategi ini dilakukan untuk mencegah dan menghindari timbulnya kenakalan remaja. Penyuluhan atau sosialisasi dilakukan untuk memberikan peringatan kepada setiap remaja akan bahaya dan dampak dari kenakalan remaja, jangan sampai remaja terjerumus dan terpengaruh dengan

11 Bangsawan, KAPOLSEK Kec. Belawa, wawancara oleh penulis di Belawa, 09 November 2017 
kenakalan remaja karena itu dapat membahayakan dirinya sendiri maupun orang lain.

\section{Patroli}

Berbicara masalah remaja memang tidak ada hentinya.Apalagi mengingat masa sekarang ini remaja sangat mudah terpengaruh dengan lingkungan sekitarnya. Bagus saja kalau pengaruhnya mengarah kepada yang positif dalam hal kebaikan, membantu orang lain dan bermanfaat di lingkungan sekitarnya, tetapi bagaimana jika terpengaruh pada hal negatif, nah ini yang salah dan sangat dihindari. Apalagi jika terjerumus pada kenakalan remaja.

Untuk menghindari adanya kenakalan remaja, maka dari itu pihak kepolisian selaku pihak yang memang bertanggungjawab akan keamanan dan ketentraman masyarakat melakukan strategi yaitu patroli sebagaimana yang dikatakan Bapak Kapolsek Kecamatan Belawa sebagai berikut:

"Kita ini di Kecamatan Belawa bersatu bersama TRIPIKA, terus Lurah/Kepala Desa, termasuk ada namanya di sini di POLRI BABINKAMTIBMAS ada di koramil BABINSA itu kita bersatu menanggulangi jadi cara menanggulanginya kita laksanakan patroli di sekolah-sekolah pada jam istirahat, pada malam hari yang diperkirakan mungkin terjadi kenakalan remaja di suatu tempat. Di tempat-tempat yang rawan untuk terjadinya kenakalan remaja"12

Strategi dengan melakukan patroli digolongkan dalam tindakan yang sifatnya preventif. Strategi patroli ini bersifat preventif karena dengan melakukan patroli di berbagai tempat seperti di sekolah maupun di lingkungan masyarakat, remaja akan lebih berfikir untuk tidak melakukan kenakalan. Tindakan preventif dengan melakukan patroli ini bertujuan untuk mencegah timbulnya kenakalankenakalan.

\section{Razia ke Penjual-Penjual}

Berbagai upaya yang dilakukan agar kenakalan remaja bisa terus dikurangi. Di Kelurahan Belawa kasus minuman keras bisa dikatakan hampir di

\footnotetext{
${ }^{12}$ Bangsawan, KAPOLSEK Kec. Belawa, Wawancara oleh penulis di Belawa, Tanggal 09 November 2017
} 
setiap pelosok ada dan remaja sering mengkonsumsinya begitupun jenis kenakalan remaja yang lain. Salah satu upaya dalam penanggulangan kenakalan remaja ini adalah merazia penjual-penjual yang menjual barang itu.Bisa saja penjualnya memang ada di Kelurahan Belawa, tetapi bisa juga berasal dari luar daerah Kelurahan Belawa. Berikut adalah hasil wawancara dengan Kapolsek Kecamatan Belawa:

"Ya jadi strateginya kita operasi di penjual-penjual minuman keras, kemudian yang penjual-penjual lem fox itu kita berikan penyuluhan jangan diberikan anak-anak, pemuda dan remaja termasuk anak sekolah jangan kasi beli.Kalo alasan orangtuanya suruh jangan, orang tuanya yang suruh pergi beli.Supaya tidak terlalu mudah remaja menggunakan itu lem fox.Termasuk itu kita operasi yang penjual-penjual minuman keras."13

Strategi dengan melakukan razia ke penjual-penjual merupakan tindakan yang sifatnya represif dalam menanggulangi masalah kenakalan remaja. Razia ke penjual-penjual ini dilakukan untuk mengurangi adanya penjualan yang bisa membuat kenakalan remaja semakin parah, misalnya minuman keras, komix maupun lem fox. Hal ini bertujuan untuk menindak penjual-penjual agar diberikan peringatan secara lisan maupun tertulis untuk menghalangi lebih parahnya kenakalan remaja.

\section{Perhatian Orangtua}

Orangtua merupakan tempat dimulainya pendidikan anak mulai dari batita, balita, anak-anak hingga memasuki masa remaja.Peran dan perhatian orangtua sangatlah diperlukan seorang anak.Orangtua adalah salah satu strategi dalam upaya preventif yang sangatlah efektif dalam mencegah terjadinya kenakalan remaja. Perhatian orangtua sangatlah berperan penting dalam memberikan pengertian terhadap anak seperti keterangan yang penulis dapatkan dari hasil wawancara sebagai berikut:

"Bagaimana cara parentingnya, pendidikan orangtua terhadap anak. Jadi harus parenting.Bagaimana orangtua mendidik anak.itu yang paling penting kalo menurut saya karena itu pengalaman saya.Itu yang paling

\footnotetext{
${ }^{13}$ Bangsawan, KAPOLSEK Kec. Belawa, Wawancara oleh penulis di Belawa, Tanggal 09 November 2017
} 
utama.Jangki salahkan lingkungan apa-apa semua, yang disalahkan orangtua, tanggungjawab orangtua.",

Jadi intinya perhatian orangtua adalah salah satu cara untuk memberikan tindakan yang sifatnya preventif kepada anak sehingga terhindar dari kenakalan remaja. Ketika apa yang dibutuhkan anak dan pengertian serta perhatian orangtua itu selaras maka anak juga akan betah tinggal dirumah dan tidak terpengaruh dengan ajakan-ajakan teman apabila dia keluar rumah.

Strategi dengan perhatian orangtua selain sifatnya preventif juga sifatnya represif dan kuratif. Tindakan represif karena orangtua yang tugasnya mendidik juga harus memberikan pembelajaran misalnya hukuman ketika anak melakukan kesalahan baik itu di dalam rumah maupun di luar rumah. Pemberian hukuman ini agar remaja jera atas apa yang dilakukannya. Sedangkan strategi perhatian orangtua yang sifatnya kuratif karena ada remaja yang bisa sadar melalui orang lain da nada juga remaja yang memang bisa sadar melalui orangtua, karena tindakan kuratif ini dilakukan untuk memberikan lagi pembinaan kepada remaja agar mengubah kembali tingkah lakunya kearah yang lebih lagi.

\section{Penanaman Ilmu Agama (Cinta Shalat dan Cinta Al-Qur'an)}

Bagi anak remaja sangat diperlukan adanya pemahaman, pendalaman serta ketaatan terhadap ajaran-ajaran agama. Dalam kenyataan sehari-hari menunjukkan bahwa anak-anak remaja yang melakukan kejahatan sebagian besar kurang memahami norma-norma agama bahkan mungkin lalai menunaikan perintah-perintah agama.

Sebagai umat muslim hendaknya kita menunaikan dan menjalankan apa yang telah diperintahkan oleh Allah SWT. Pembinaan sejak dini seharusnya sudah dilakukan mulai dari pembinan orangtua, guru disekolah, guru mengaji dan guruguru di tempat belajar nonformal lainnya.

\footnotetext{
${ }^{14}$ M. Anwar Orangtua remaja Kel. Belawa, Kec. Belawa, Wawancara oleh penulis di Belawa, Tanggal 09 November 2017
} 
Najia Angraini, Strategi Penanggulangan Kenakalan...

\section{Pengaruh Strategi Penanggulangan terhadap Kenakalan Remaja}

Berbagai strategi penanggulagan yang dilakukan oleh pemerintah setempat, baik itu dari Kelurahan, Kecamatan, masyarakat, tokoh agama maupun dari pihak kepolisian, perlu adanya evaluasi untuk mengukur bagaimana tingkat keberhasilan yang telah dilakukan dalam menanggulangi kenakalan remaja ini. Strategi penangggulangan yang dilakukan apakah berpengaruh atau tidak pada remaja-remaja di Kelurahan Belawa ini dapat dilihat pada tabel di bawah ini.

Tabel: Strategi Penanggulangan, Sifat dan Pengaruhnya

\begin{tabular}{|l|l|l|l|}
\hline No & Strategi Penanggulangan & \multicolumn{1}{|c|}{ Sifat } & \multicolumn{1}{c|}{ Pengaruh } \\
\hline 1 & Penyuluhan/Sosialisasi & Preventif & Kurang Efektif \\
\hline 2 & Patroli & Preventif & Kurang Efektif \\
\hline 3 & Razia ke Penjual-Penjual & Represif & Efektif \\
\hline 4 & Perhatian Orangtua & $\begin{array}{l}\text { Preventif, } \\
\text { Represif, Kuratif }\end{array}$ & Cukup Efektif \\
\hline 5 & Penanaman Ilmu Agama & Preventif, Kuratif & Cukup Efektif \\
\hline
\end{tabular}

\section{Tindakan Preventif}

Tindakan preventif yang dilakukan pemerintah Kelurahan Belawa bekerjasama dengan Kapolsek Kecamatan Belawa yaitu dengan melakukan strategi penyuluhan/sosialisasi, patroli, perhatian orangtua dan penanaman ilmu agama. Adapun pengaruh dari strategi tersebut menurut bapak M. Anwar adalah sebagai berikut:

"Yang pernah dilakukan oleh pemerintah karena saya tidak pernah melakukan kalo saya pernah lakukan hanya pada ee pendidik karena saya kan dari pendidik toh. Jadi saya melakukan tentang sosialisasi begitu kan Saya sering juga singgung persoalan begitu di orangtua anak, guru-guru kelompok bermain karena itu parenting, pendidikan orangtua terhadap anak. kemudian dampaknya apakah ada pengaruh. Ada tapi ya tidak terlalu, ada sih ada artinya yaa sekitar-sekitar 34 bulan tidak diingat lagi persoalan-persoalan begitu ya masuk lagi."

\footnotetext{
${ }^{15}$ M. Anwar Orangtua remaja Kel. Belawa, Kec. Belawa, Wawancara oleh penulis di Belawa, Tanggal 09 November 2017
} 
Najia Angraini, Strategi Penanggulangan Kenakalan...

Berdasarkan hasil wawancara dengan bapak M.Anwar yang juga bekerja sebagai tenaga pendidik menurut penulis bahwa pengaruh strategi dari strategi penanggulangan yang pernah dilakukannya sebagai tenaga pendidik memang ada pengaruhnya, namun itu tidak banyak membantu karena selang beberapa bulan akan terjadi lagi.

Strategi penanggulangan kenakalan remaja di Kelurahan Belawa menurut penulis sudah cukup maksimal untuk mengurangi dan menanggulangi kenakalan remaja yang ada di Kelurahan Belawa, mulai dari penyuluhan kemudian patroli ke tempat-tempat yang memang rawan terjadi kenakalan remaja dan itu sudah dibilang kurang.

\section{Tindakan Represif}

Tindakan Represif yakni tindakan untuk menindak pelanggaran yang dilakukan remaja dapat dilakukan dengan mengadakan hukuman terhadap setiap perbuatan pelanggaran yang dilakukan agar ada efek jera atas apa yang telah remaja lakukan. Tindakan represif yang dilakukan pemerintah Kelurahan Belawa bekerjassama dengan Kapolsek Kecamatan Belawa yakni dengan merazia penjual-penjual dan dengan perhatian orangtua.

Memang tidak bisa dipungkiri, remaja yang terus-terusan berbuat kenakalan tidak mempunyai sama sekali efek jera, buktinya setelah remaja melakukannya dan telah diberikan pembinaan oleh pihak yang berwenang, tetap saja hal itu masih saja dilakukannya. Dari hasil wawancara dengan Lurah Kelurahan Belawa, menurut penulis bahwa upaya pemerintah dalam menanggulangi kenakalan remaja yaitu penjualan minuman keras di Belawa sudah berkurang, karena pengurangan dari botol-botol minuman keras yang ditemukan sudah berkurang, yang dulunya bisa 1-2 lusin dan bulan September kemarin hanya ditemukan 6 botol minuman keras. Strategi pemerintah setempat dalam menindak kenakalan remaja ini sudah efektif dan cukup maksimal, walaupun yang mengonsumsi barang tersebut masih ada. 
Najia Angraini, Strategi Penanggulangan Kenakalan...

\section{Tindakan Kuratif}

Tindakan kuratif yang dilakukan oleh pemerintah Kelurahan Belawa bekerjasama dengan Kapolsek Kecamatan Belawa, tokoh agama serta masyarakat yakni dengan strategi perhatian orangtua dan penanaman ilmu agama.Strategi tersebut untuk memberikan pembinaan kepada remaja yang pernah melakukan kenakalan untuk tidak berbuat kenakalan lagi. Kemudian dengan tindakan kuratif ini agar remaja bisa sadar akan perbuatannya dan lebih memperbaiki perbuatannya lagi.

Pihak kepolisian yang memang berwenang dalam menanggulangi masalah kenakalan remaja ini sudah melakukan upaya penanggulangan secara bertahap, penyuluhan di sekolah-sekolah, operasi dibeberapa tempat, kemudian patroli sampai kepada tahap pembinaan remaja. Pembinaan remaja oleh pihak kepolisian dilakukan dengan memanggil orangtua remaja, tapi yang masih sekolah akan dipanggil gurunya dan dilakukan pembinaan.

Tahap pembinaan remaja memang perlu untuk dilakukan karena tindakan kuratif ini sebagaimana yang sudah dijelaskan di BAB 2 bahwa remaja perlu diberikan pembinaan secara khusus agar dapat mengubah tingkah laku remaja dan memang ini dilakukan oleh lembaga khusus dan memang ahli dibidangnya seperti dipihak kepolisian yang memang menangani hal itu.

Beberapa strategi yang dilakukan pemerintah Kelurahan Belawa dalam menangani masalah kenakalan remaja yang tergolong dalam 3 yaitu tindakan preventif, tindakan represif, dan tindakan kuratif.Tindakan preventif yang dilakukan pemerintah Kelurahan Belawa yaitu penyuluhan/sosialisasi, patroli, perhatian orangtua, dan penanaman ilmu agama.Tindakan represif yaitu razia ke penjual-penjual, dan perhatian orangtua.Sedangkan tindakan kuratif yaitu melalui perhatian orangtua dan penanaman ilmu agama.

Dari beberapa strategi penanggulangan yang dilakukan pemerintah Kelurahan Belawa tindakan preventif lebih banyak dilakukan dalam mengatasi kenakalan remaja.Tindakan preventif ini bagaimana untuk mencegah terjadinya kenakalan remaja lebih parah lagi.Maka dari itu pemerintah melakukan strategi 
penanggulangan yang sifatnya preventif namun itu belum terlalu efektif untuk menanggulangi kenkalan remaja.

Strategi penanggulangan kenakalan remaja yang dilakukan pemerintah Kelurahan Belawa Kecamatan Belawa sudah maksimal, namun memang susah ketika bukan kesadaran dari remaja itu sendiri yang menyadari akan hal itu. Kemudian enggannya masyarakat memberikan informasi ketika menemukan kenakalan remaja dan itu merupakan kendala dari pihak kepolisian dalam menanggulangi kasus kenakalan remaja. Pemerintah Kelurahan Belawa bekerja sama dengan Kapolsek Kecamatan Belawa, tokoh agama, tokoh masyarakat dalam mengurangi kenakalan remaja ini.

\section{PENUTUP}

\section{Kesimpulan}

Bentuk-bentuk kenakalan remaja yang terjadi di Kelurahan Belawa antara lain: balapan liar dan ugal-ugalan, menggunakan lem (lem fox), minum minuman oplosan (komix), minum minuman keras, dan narkoba. Ada beberapa strategi yang dilakukan oleh pihak kepolisian bekerjasama dengan pemerintah Kelurahan Belawa, tokoh agama, dan masyarakat yang sifatnya preventif, represif dan kuratif. Tindakan Preventif di antaranya: penyuluhan/sosialisasi, patroli, perhatian orangtua, dan penanaman ilmu agama. Tindakan represif di antaranya: razia ke penjual-penjual dan perhatian orangtua. Tindakan kuratif di antaranya: perhatian orangtua dan penanaman ilmu agama.

Adapun pengaruh dari penanggulangan kenakalan remaja yang dilakukan oleh pemerintah Kelurahan Belawa sudah cukup maksimal. Strategi penanggulangan kenakalan remaja yang dilakukan oleh pemerintah Kelurahan Belawa, tokoh agama, dan orangtua sudah cukup maksimal. Tindakan yang sifatnya preventif belum efektif karema masih banyak remaja yang masih melakukan kenaklan. Tindakan represif sudah efektif dilakukan karena sudah adanya pengurangan kenakalan semenjak dilakukan strategi yang sifatnya represif. Kemudian tindakan kuratif juga sudah dilakukan dan itu sduah cukup efektif. 
Najia Angraini, Strategi Penanggulangan Kenakalan...

\section{DAFTAR PUSTAKA}

Bungin, Burhan2007. Sosiologi Komunikasi: Teori, Paradigma, dan Diskursus Teknologi di Masyarakat, Cet 2; Jakarta: Kencana Prenada Media Group.

Basrowi dan Suwandi, 2008. Memahami Penelitian Kualitatif, Cet. I, Jakarta: PT Renika Cipta.

Devito, Joseph A, 1997. Komunikasi Antarmanusia. Cet. V; Jakarta: Profesional Books.

Denzin, Norman K \& Yvonna S. Lincoln (eds), 2009. Handbook of Qualitative Research, terj. Dariyanto, badru samsu fata dan Jhon Rinald, Handbook of Qualitative Research (Yogyakrta: Pusaka Pelajar).

Effendy, Onong Uchjana, Ilmu Komunikasi Teori Dan Praktek

Feldman S Robert, 2012, Pengantar Psikologi (Edisi 10 buku 2, Jakarta: Salemba Humanika)

Moleong, Lexy J. 1998. Metodeologi Penelitian Kualitatif, Cet. IV, Jakarta: PT Rineka Cipta.

Mulyana, Deddy, 2008. Metode Penelitian Kualitatif, Paradigma baru ilmu penelitian komunikasi dan ilmu sosial lainnya,Cet. V; Bandung: Remaja Rosdakarya.

Rahmat Jalaluddin, 2007 Psikologi Komunikasi, Bandung: PT Remaja Rosdakarya. 